University of Pennsylvania Carey Law School

Penn Carey Law: Legal Scholarship Repository

Faculty Scholarship at Penn Carey Law

$9-6-2022$

\title{
Solving the Congressional Review Act's Conundrum
}

\author{
Cary Coglianese \\ University of Pennsylvania Carey Law School
}

Follow this and additional works at: https://scholarship.law.upenn.edu/faculty_scholarship

Part of the Administrative Law Commons, American Politics Commons, Banking and Finance Law Commons, Constitutional Law Commons, Law and Politics Commons, Legislation Commons, and the Public Administration Commons

\section{Repository Citation}

Coglianese, Cary, "Solving the Congressional Review Act's Conundrum" (2022). Faculty Scholarship at Penn Carey Law. 2166.

https://scholarship.law.upenn.edu/faculty_scholarship/2166

This Article is brought to you for free and open access by Penn Carey Law: Legal Scholarship Repository. It has been accepted for inclusion in Faculty Scholarship at Penn Carey Law by an authorized administrator of Penn Carey Law: Legal Scholarship Repository. For more information, please contact PennlawIR@law.upenn.edu. 


\title{
Solving the Congressional Review Act's Conundrum
}

\author{
Cary Coglianese \\ University of Pennsylvania Law School
}

\begin{abstract}
$\underline{\text { Abstract }}$
Congress routinely enacts statutes that require federal agencies to adopt specific regulations. When Congress passed the Dodd-Frank Wall Street Reform and Consumer Protection Act in 2010, for example, it mandated that the Securities and Exchange Commission (SEC) adopt an anticorruption regulation requiring energy companies to disclose payments they make to foreign governments. Although the Dodd-Frank Act specifically required the SEC to adopt this disclosure requirement, the agency's eventual regulation was also, like other administrative rules, subject to disapproval by Congress under a process outlined in a separate statute known as the Congressional Review Act (CRA).
\end{abstract}

After the SEC issued its final disclosure rule as required under the Dodd-Frank Act, Congress passed a joint resolution disapproving the rule under the process authorized in the CRA. Although that disapproval resolution nullified the SEC's rule, it did not amend the Dodd-Frank Act nor eliminate the statutory command that the SEC adopt a disclosure rule like the very one that Congress had disapproved. Yet the passage of the CRA resolution did trigger a provision in the CRA that prohibits an agency from adopting any subsequent regulation that is "substantially the same" as one that Congress has disapproved. The SEC, in other words, still needed to issue a disclosure regulation, but it could not issue one that was substantially the same as the old one.

In some instances, this might not pose a major problem for an agency, but the SEC found itself in a bind because the Dodd-Frank Act not only required the agency to adopt a disclosure regulation, the statute also provided considerable detail about what needed to be included in that regulation. What emerged was a conundrum - the CRA conundrum - created by the tension between the CRA and substantive statutes such as the Dodd-Frank Act. On the one hand, agencies face statutory mandates to adopt regulations that comport with the detailed provisions of a substantive statute, such as the Dodd-Frank Act. On the other hand, if these agencies' regulations are then disapproved, they can no longer adopt a regulation that is "substantially the same" as the old regulation.

What is an agency to do? Is there a way for agencies to overcome the CRA conundrum, remaining faithful to both the CRA's "substantially the same" limitation and the detailed requirements of a substantive statute that mandates regulatory action? In this article, I use the SEC's predicament to highlight and then tackle the CRA conundrum - one that other agencies have confronted and will continue to confront in the future whenever CRA resolutions disapprove of statutorily mandated rules.

The key to resolving the conundrum is to recognize that Congress's choice of imprecision in the CRA allows agencies to follow the more specific language contained in substantive statutes, such as the Dodd-Frank Act. The test for substantial similarity in cases of statutory tension must be measured against the discretion the substantive statute affords the agency. A general statute such as 
the CRA, after all, can only impose obligations on an agency with respect to matters over which it has discretion. An agency that finds itself facing the CRA conundrum simply needs to make sure that any re-issued rule is no longer substantially the same as those portions of the rule over which the substantive statute allowed the agency room to maneuver.

What counts as "substantial," then, will necessitate an initial judgment about the space available to the agency to act. Even with highly detailed statutory provisions, an agency will almost always still have some discretion available to it over some of the rule's terms. That discretion must then be exercised in some substantially different way, even if only by making available opportunities for waivers or by extending deadlines for compliance. In the end, the disapproval of a rule under the CRA does not relieve an agency from its obligation to produce a regulation that complies with other statutory obligations but, by viewing "substantial" from the proper perspective, the CRA conundrum can be solved. 


\title{
Solving the Congressional Review Act Conundrum
}

\author{
Cary Coglianese*
}

Congress routinely enacts statutes mandating that federal agencies adopt specific regulations. When it passed the Dodd-Frank Wall Street Reform and Consumer Protection Act in 2010, for example, Congress required the Securities and Exchange Commission (SEC) to adopt an anti-corruption regulation that would compel energy companies to disclose payments they make to foreign governments. ${ }^{1} \mathrm{But}$ substantive statutes such as the Dodd-Frank Act must be implemented in accordance with more general procedural statutes that govern the rulemaking process. And sometimes these procedural statutes can come into tension with substantive statutes.

The Dodd-Frank Act specifically required the SEC to mandate that energy firms publicly disclose information about their payments to government officials. That disclosure regulation was, like any regulation, subject to a process outlined in a separate statute known as the Congressional Review Act (CRA), which authorizes Congress to take steps to disapprove an agency regulation. ${ }^{2}$ In 2017 , Congress followed the process authorized in the CRA to pass a joint resolution that disapproved the SEC's disclosure rule. ${ }^{3}$ In doing so, Congress presented the SEC with a conundrum created by an apparent tension between the CRA and the Dodd-Frank Act.

\footnotetext{
* Edward B. Shils Professor of Law, University of Pennsylvania Law School; Director, Penn Program on Regulation. Copyright (C) 2022 by Cary Coglianese. All rights reserved. I gratefully acknowledge helpful comments from Lavi Ben Dor and research assistance by Alexis Désiré, Richard Dinapoli, and Jasmine Wang. This article is forthcoming in the Administrative Law Review.

${ }^{1}$ Dodd-Frank Wall Street Reform and Consumer Protection Act, Pub. L. No. 111-203, § 1504, 124 Stat. 1376, 2220-2222 (2010).

${ }^{2}$ Congressional Review Act, 5 U.S.C. $\S \S 801-808$ (2018).

${ }^{3}$ Pub. L. No. 115-4, 131 Stat. 9 (2017).
} 
That conundrum came about because, while Congress's 2017 resolution of disapproval nullified the SEC's disclosure rule, it did not amend the Dodd-Frank Act. It nevertheless did trigger a provision in the CRA that prohibits an agency from adopting any future regulation that is "substantially the same" as one that Congress has disapproved. ${ }^{4}$ As a result, the SEC still needed to issue a regulation that would mandate energy companies disclose their payments to foreign governments, but it could not issue one that would be substantially the same as the old one. Although perhaps sometimes this might not pose a major problem for an agency, the two statutes placed the SEC in what one SEC Commissioner aptly described as a "difficult situation" because the DoddFrank Act not only required the SEC to issue a disclosure regulation, it also provided considerable detail about what the agency needed to make sure that regulation said. ${ }^{6}$

The SEC thus faced a "novel and complex" puzzle. ${ }^{7}$ On the one hand, the agency needed to adopt a regulation that comported with the detailed provisions of the Dodd-Frank Act. But on the other hand, it was prohibited under the CRA from adopting a regulation that would be "substantially the same" as the old regulation. What was the agency to do? The SEC eventually announced a proposal for a new disclosure regulation, Rule $13 \mathrm{q}-1,{ }^{8}$ that differed in several ways from the old one - thereby purportedly comporting with the CRA - but the proposed regulation also appeared in important respects to be inconsistent with the Dodd-Frank Act's requirements for how

\footnotetext{
${ }^{4} 5$ U.S.C. $\$ 801(b)(2)$.

${ }^{5}$ Caroline A. Crenshaw, Statement on Resource Extraction (Dec. 16, 2020), https://www.sec.gov/news/public-statement/crenshaw-statement-resource-extraction.

${ }^{6}$ See 15 U.S.C. $\S 78 \mathrm{~m}(\mathrm{q})(2)(\mathrm{A})$ (obligating the SEC to promulgate final rules that "require each resource extraction issuer to include in an annual report of the resource extraction issuer information relating to any payment made by the resource extraction issuer [or a related entity] to a foreign government or the Federal Government for the purpose of . . . commercial development").

${ }^{7}$ Crenshaw, supra note 5; $c f$. ROBERT A. KATZMANN, JUdGing STATUTES x (2014) (observing how "unlocking the meaning of an unclear statute ... is often much like trying to solve a puzzle").

${ }^{8}$ Disclosure of Payments by Resource Extraction Issuers, 85 Fed. Reg. 2522 (Jan. 15, 2020) (proposed rule).
} 
the disclosure rule should be designed. ${ }^{9}$ To solve the CRA conundrum, did the agency need to contravene one statute to comport with another?

A considerable corpus of legal commentary has focused over the years on the Congressional Review Act. ${ }^{10}$ Other scholars have identified and grappled with the ambiguity inherent in the CRA's "substantially the same" limitation. ${ }^{11}$ But the conundrum created by the CRA's limitation in the face of substantive statutes mandating a regulation similar to one disapproved by Congress has so far escaped attention, even though the problem has already arisen for agencies such as the SEC and will continue to arise in the future. ${ }^{12}$

\footnotetext{
${ }^{9}$ See infra notes 36-39 and accompanying text.

${ }^{10}$ See Jody Freeman \& Matthew C. Stephenson, The Untapped Potential of the Congressional Review Act, 59 HARV. J. LEG. 279 (2022); Bridget C.E. Dooling, Into the Void: The GAO's Role in the Regulatory State, 70 AM. U.L. REV. 387 (2020); Keith Bradley \& Larisa Vaysman, CRA Resolutions Against Agency Guidance, 4 U. PA. J. L. \& PUB. AFF. 459 (2019); Michael J. Cole, Interpreting the Congressional Review Act: Why the Courts Should Assert Judicial Review, Narrowly Construe "Substantially the Same," and Decline to Defer to Agencies Under Chevron, 70 ADMIN. L. REV. 53
} (2018); Paul J. Larkin, Jr., The Trump Administration and the Congressional Review Act, 16 GEO. J.L. \& PUB. POL'Y 505 (2018); Paul J. Larkin, Jr., Reawakening the Congressional Review Act, 41 HARV. J.L. \& PUB. POL'Y 187 (2018); Adam M. Finkel \& Jason W. Sullivan, A Cost-Benefit Interpretation of the "Substantially Similar" Hurdle in the Congressional Review Act: Can OSHA Ever Utter the E-Word (Ergonomics) Again?, 63 ADMIN. L. REV. 707 (2011); Sean D. Croston, Congress and the Courts Close Their Eyes: The Continuing Abdication of the Duty to Review Agencies' Noncompliance with the Congressional Review Act, 62 ADMIN. L. REV. 907 (2010); Julie A. Parks, Lessons in Politics: Initial Use of the Congressional Review Act, 55 ADMIN. L. REV. 187 (2003).

${ }^{11}$ See, e.g., Finkel \& Sullivan, supra note 10, at 710 (arguing that a rule will not be substantially the same as a disapproved rule long as it has "a significantly more favorable balance of costs and benefits than the vetoed rule"); Cole, supra note 10, at 83-94 (outlining seven possible approaches to interpreting "substantially the same" and generally endorsing the approach taken by Finkel and Sullivan).

${ }^{12}$ On the continuing appeal of using the CRA to disapprove of rules, see Bethany A. Davis Noll \& Richard L. Revesz, Regulation in Transition, 104 MINN. L. REV. 1, 23 (2019) (observing that the CRA will remain "an attractive tool for a future administration with unitary party control of the presidency, House, and Senate, which seeks to undo its predecessor's regulatory policies"). The only other work of legal scholarship that I have been able to identify that gives anything more than a passing reference to the CRA conundrum simply discusses and cites approvingly my analysis here, which was previously issued as a working paper. John C. Ruple \& Devin Stelter, Charting a "Substantially Different" Approach to Land Management Planning Following a Congressional Review Act Joint Resolution of Disapproval, 12 ARIZ. J. ENVTL. L. \& POL'Y 84 (2021) (“We agree with Professor Coglianese that the prohibition against 
Although the CRA conundrum looks intractable, it can be resolved. The CRA's choice of the imprecise word "substantially" invites reconciliation between the CRA and any seemingly conflicting statutory demands. An agency can proceed by ensuring that those features of a new regulation that remain within the agency's discretion are not substantially the same as the old rule. After all, a statute such as the CRA can only impose an obligation on an agency with respect to matters over which the agency has a choice. The agency just needs to make sure that any re-issued rule is no longer substantially the same in terms of portions of the rule over which the agency can exercise its discretion. Even with highly detailed statutory provisions, an agency nevertheless will still have some discretion available to it which can be exercised in a substantially different way, even if only by, for example, extending deadlines for compliance or making available opportunities for waivers.

To put the point more generally, any assessment of whether a subsequent rule is "substantially the same" as an earlier disapproved rule must be made with reference to the discretion the substantive statute affords an agency in designing the rule. A congressional disapproval resolution under the CRA does not relieve an agency from its obligation to produce a regulation that complies with other statutory obligations. Such a disapproval resolution does not amend the substantive statute, nor does it eliminate the substantive statute's requirement that the agency adopt a rule that meets certain criteria or contains specified elements. What counts as a substantial similarity or difference between two rules thus cannot be made simply by comparing the rules on their face, completely divorced from the substantive statute's mandate. When

issuing a rule that is 'substantially the same' as a previously disapproved rule is best understood in light of agency discretion.”). 
Congress has required an agency to adopt a rule that Congress later disapproves, the approach that best respects both the statutory prohibition in the CRA and statutory requirement in the substantive law is to look to see whether the agency has exercised its discretion in substantially the same manner.

In Part I of this article, I elaborate the nature of the CRA conundrum, using the recent predicament of the SEC as an illustration. Although this one agency's predicament suffices for the purpose of illustrating the CRA conundrum, other agencies have faced it or will face it in the future. ${ }^{13}$ Having illustrated the predicament by reference to the SEC's disclosure rule, I then proceed in Part II to present a spatial account of regulatory discretion and show how it solves the CRA conundrum. I explain why the appropriate measure of the similarity of a subsequent rule must take into account the amount of discretion — that is, the decision-making space — available to the agency in adopting it. ${ }^{14}$ Finally, in part III, I take up possible alternative arguments that rely on Chevron deference and on the legislative history underlying a resolution of disapproval. I show that these alternative accounts cannot dissolve the CRA conundrum. In the end, the solution lies in the spatial understanding presented in Part II.

Ultimately, tackling the CRA conundrum is important not merely for resolving the seeming uncertainty arising from a disapproved rule, especially given that the prospect of

\footnotetext{
${ }^{13}$ The U.S. Department of Labor, for example, confronted a situation in which Congress disapproved a rule under the CRA even though "the statute continues to require the Secretary to issue regulations" addressing the very issue as the disapproved rule. U.S. Department of Labor, Federal-State Unemployment Compensation Program, 84 Fed. Reg. 53,037, 53,037 (Oct. 4, 2019).

${ }^{14}$ In fact, after I presented the analysis in this article to the SEC, in the form of a comment on its proposed rule reissuing its disclosure rule after Congress's disapproval, the SEC adopted the basic conceptual framework provided here. See infra notes 82-83 and accompanying text.
} 
continued use of CRA disapprovals looms in the future. ${ }^{15}$ It is also important because examination of the CRA conundrum provides still more general insights to the kinds of challenges of legal interpretation presented in era of growing and increasingly complex statutory law. ${ }^{16}$ Today, as ever before, agencies and courts will confront apparent conflicts between statutes and must find ways to reconcile them so that agencies can meet all the demands that Congress has imposed on them.

\section{The Dodd-Frank Act, Rule 13q-1, and the CRA Conundrum}

The CRA conundrum is not just an intellectual puzzle. It has in fact arisen, and it poses real-world challenges for regulatory agencies. To ground the conundrum in the reality confronting agencies, I begin with a brief explication of the SEC's predicament surrounding the Dodd-Frank Act's requirement that the SEC establish a rule on the disclosure of energy extraction firms' payments to governmental entities. I then turn to the CRA itself and show how Congress's disapproval of the SEC's disclosure rule, combined with the CRA's "substantially the same" limitation, create what I have called the CRA conundrum.

\section{A. The SEC's Implementation of the Dodd-Frank Act's Rulemaking Mandate}

In 2010, Congress enacted section 1504 of the Dodd-Frank Wall Street Reform and Consumer Protection Act. ${ }^{17}$ This provision instructed the SEC to adopt a rule requiring detailed

\footnotetext{
${ }^{15}$ Bethany Davis Noll \& Richard L. Revesz, Regulatory Rollbacks Have Changed the Nature of Presidential Power, REG. REV. (Mar. 16, 2020), https://www.theregreview.org/2020/03/16/davis-nollrevesz-regulatory-rollbacks-changed-nature-presidential-power/.

${ }^{16}$ GUIDO CALABRESI, COMMON LAW FOR THE AGE OF STATUTES (1982).; ROBERT KATZMAN, JUdGING STATUTES (2014).

${ }^{17}$ Dodd-Frank Wall Street Reform and Consumer Protection Act, Pub. L. No. 111-203, § 1504, 124 Stat. 1376, 2220-2222 (2010).
} 
reporting of payments made by natural resource extraction companies to governmental entities, as a way of addressing concerns about corruption in countries that are rich in natural resources, such as oil. ${ }^{18}$ The statute's language was detailed and specific. Through its approximately 800 words, the statute directed the SEC, among other things, to issue a rule that accords with express statutory definitions for integral terms, such as "payments" and "resource extraction issuers."19

In response to the statutory mandate in section 1504, the SEC initially adopted a final rule in $2012 .^{20}$ The brief text of this initial version of Rule $13 \mathrm{q}-1$ simply required resource extraction issuers to file reports using the SEC's Form SD (which stands for "specialized disclosure"). ${ }^{21}$ Form SD, in turn, required the disclosure of all payments made to the U.S. government or a foreign government for the purpose of the commercial development of oil, natural gas, or minerals. ${ }^{22}$ Under the SEC's rule, entities needed to file Form SD using the SEC's EDGAR portal, which makes filings publicly available. ${ }^{23}$ This initial version of the rule, however, was subsequently vacated in 2013 by the U.S. District Court for the District of Columbia because the court found the rule to be arbitrary and capricious due to its "denial of any exemption for countries that prohibit payment disclosure." The court also held that the SEC had erroneously interpreted section 1504 to mandate public disclosure of all reports. ${ }^{24}$

\footnotetext{
${ }^{18} 15$ U.S.C. $\S 78 \mathrm{~m}(\mathrm{q})$ (2018). Although the animating purpose of this provision stemmed from concerns about payments of bribes to officials in foreign governments, the statute and subsequent rule made clear that it applied as well to payments made to the U.S. federal government.

${ }^{19} I d$. at $\S 78 \mathrm{~m}(\mathrm{q})(2)(\mathrm{A})$.

${ }^{20}$ Disclosure of Payments by Resource Extraction Issuers, 77 Fed. Reg. 56,365 (Sept. 12, 2012).

${ }^{21} I d$. at 56,417 .

${ }^{22} I d$. at 56,418 . The rule provided an exception to disclosure for "de minimis" payments, defined as a payment or a series of related payments of no more than $\$ 100,000$. Id. at 56,419 .

${ }^{23} I d$.

${ }^{24}$ Am. Petroleum Inst. v. SEC, 953 F. Supp. 2d 5, 11, 20 (D.D.C. 2013).
} 
On remand from the district court, the SEC issued a new rule in $2016 .{ }^{25}$ This version, like the 2012 rule, required resource extraction companies to make disclosures using Form SD and the EDGAR portal. ${ }^{26}$ Among the changes the SEC made to the 2012 version, the agency added a provision designed to defeat schemes to evade the required disclosure and it authorized issuers to seek permission to follow an alternate reporting regime or to obtain an exemption from the rule's disclosure requirements. It also indicated that, rather than making each company's report public, the SEC would merely make periodic public reports compiling the information disclosed under the rule. ${ }^{27}$

This second iteration of the rule also met with resistance. Representatives of industry, as well as members of Congress, complained that the rule imposed burdensome compliance costs on energy firms. ${ }^{28}$ In 2017, Congress passed, and the president signed, a joint resolution disapproving the rule ${ }^{29}$ under the procedures outlined in the CRA. ${ }^{30}$ Upon President Donald Trump's signing of the joint resolution of disapproval, the 2016 disclosure rule was null and void.

Perhaps buoyed by the aphorism "the third time is the charm," the SEC went to work yet again to issue the rule called for by the Dodd-Frank Act. In January 2020, the agency proposed yet another version of the rule. ${ }^{31}$ As before, the proposed rule would require the submission of

\footnotetext{
${ }^{25}$ Disclosure of Payments by Resource Extraction Issuers, 81 Fed. Reg. 49,359 (Jul. 27, 2016).

${ }^{26} I d$. at $49,426-27$.

${ }^{27}$ Id.; see also Disclosure of Payments by Resource Extraction Issuers, 85 Fed. Reg. 2522, 2525 (proposed Jan. 15, 2020) (to be codified at 17 C.F.R. pts. 240, 249b) (summarizing similarities and differences between the 2012 and 2016 rules).

${ }^{28}$ See, e.g., 163 CONG. REC. H.848 (daily ed. Feb. 1, 2017) (statement of Rep. Hensarling); 163 ConG. REC. H.852 (daily ed. Feb. 1, 2017) (statement of Rep. Barr).

${ }^{29}$ See Pub. L. No. 115-4, 131 Stat. 9 (2017).

${ }^{30} 5$ U.S.C. $\S 801-808$ (2018).

${ }^{31}$ Disclosure of Payments by Resource Extraction Issuers, 85 Fed. Reg. 2522 (proposed Jan. 15, 2020) (to be codified at 17 C.F.R. pts. 240, 249b).
} 
payment disclosures and, in other respects, it would keep many of the features of the 2016 rule. ${ }^{32}$ But it would also make some changes too. Specifically, the new version of the rule, as proposed, would have expressly exempted from the rule's disclosure requirements all resource extraction issuers for whom providing the information would be "prohibited by the law of the jurisdiction" where the projects are located or would violate any of the issuer's preexisting contracts, as long as certain conditions were met. ${ }^{33}$ The proposed rule would also broaden the "de minimis" exemption and allow exemptions for small companies and those firms going through initial public offerings ${ }^{34}$ Perhaps most significantly, the proposed rule would allow issuers to aggregate all payments of a particular type made to a level of government and disclose just the aggregated amount..$^{35}$

\section{B. Congressional Oversight and the Creation of the CRA Conundrum}

In proposing a new rule after its 2016 rule had been disapproved by Congress, the SEC found itself facing the CRA conundrum. Under the CRA, a rule that is disapproved no longer has any legal force or effect. ${ }^{36}$ Furthermore, the agency that adopted the disapproved rule is

\footnotetext{
${ }^{32} I d$. at 2567. Under the proposal, though, firms' disclosures would only need to be furnished to the SEC, rather than filed publicly.

${ }^{33} \mathrm{Id}$.

${ }^{34} I d$.

${ }^{35} \mathrm{Id}$. at 2570-71; see also id. at 2527-28 (summarizing changes made to the 2016 rules).

${ }^{36}$ For instance, the entirety of the joint resolution of disapproval of the SEC resource extraction payment disclosure rule reads as follows:
}

Resolved by the Senate and House of Representatives of the United States of America in Congress assembled, That Congress disapproves the rule submitted by the Securities and Exchange Commission relating to "Disclosure of Payments by Resource Extraction Issuers" (published at 81 Fed. Reg. 49359 (July 27, 2016)), and such rule shall have no force or effect.

131 Stat. at 9. This language follows the required template for such a disapproval resolution in the CRA. See 5 U.S.C. $\S 802(a)$. 
precluded from issuing the same rule in the future. ${ }^{37}$ The relevant provision of the CRASection 801(b)(2)—reads as follows:

A rule [disapproved under the CRA] may not be reissued in substantially the same form, and a new rule that is substantially the same as such a rule may not be issued, unless the reissued or new rule is specifically authorized by a law enacted after the date of the joint resolution disapproving the original rule. ${ }^{38}$

As the SEC noted in the preamble to its proposed rule, the CRA does not explicitly denote what the phrase "substantially the same" means. ${ }^{39}$ Moreover, no court has yet been presented with the occasion to construe these words in the CRA. ${ }^{40}$

Discerning the meaning of "substantially the same" is pivotal to resolving the CRA conundrum. As the SEC correctly acknowledged in the preamble to its 2020 proposed rule, notwithstanding the CRA disapproval of the 2016 version of the disclosure rule, the agency still

\footnotetext{
375 U.S.C. $\S 801(b)(2)$. Unlike with the district court's nullification of the SEC's 2012 rule which emanated from the order issued by the judge, the preclusion of the 2016 version stems from the CRA, rather than from any language within Congress's 2017 joint resolution of disapproval. Except for the most general heading that references "chapter 8 of title 5" of the U.S. Code, a heading that is not itself part of the enacted law, the joint resolution itself contained no language whatsoever about any limitations on the SEC's ability to adopt a subsequent administrative rule on the disclosure of payments by resource extraction issuers. See 131 Stat. at 9.

${ }^{38} 5$ U.S.C. $\S 801(b)(2)$.

${ }^{39}$ Disclosure of Payments by Resource Extraction Issuers, 85 Fed. Reg. 2522, 2526 (proposed Jan. 15, 2020) (to be codified at 17 C.F.R. pts. 240, 249b) ("The CRA does not define the phrase 'substantially the same' ....").

${ }^{40}$ It may not be immediately clear whether a court could ever be confronted with this question, as a precedent question is whether any suit for noncompliance with the CRA would be barred by section 805 of the CRA, which states that "[n]o determination, finding, action, or omission under this chapter shall be subject to judicial review." 5 U.S.C. § 805. Presumably, this limitation on judicial review would not bar a court from enforcing the CRA's prohibition on the issuance of a subsequent rule that was "substantially the same," because judicial review in such a case would be of an action based on the substantive statute, not one arising "under" the CRA. Moreover, consistent with this conclusion, federal courts have in fact entertained CRA-based challenges to agency actions. See, e.g., Ctr. for Biological Diversity v. Zinke, 313 F. Supp. 3d 976 (D. Alaska 2018); United States v. S. Ind. Gas \& Elec. Co., 2002 U.S. Dist. LEXIS 20936 (S.D. Ind. 2002).
} 
faced a statutory obligation to adopt a rule that both implemented section 1504 of the DoddFrank Act and complied with that substantive law's detailed provisions. ${ }^{41}$

But with its proposed rule, the SEC also appeared to be proposing modifications to its 2016 rule that conflicted with the Dodd-Frank Act, as several commenters on the proposed rule pointed out. In its approach to the question of whether disclosed payments can be aggregated, for example, the SEC's proposed rule appeared to conflict with the express terms of the Dodd-Frank Act, which calls for disclosure of "any payment" - not disclosure of an aggregated amount of payments. ${ }^{42}$ In addition, some commenters questions whether the SEC possessed the legal authority under the Dodd-Frank Act to enact some of the exemptions the proposed rule would allow. ${ }^{43}$ In addition, the agency arguably would come into some tension with the Dodd-Frank Act with its proposed new definition of what constitutes an energy "project" that needs to be disclosed, with the proposed rule taking a looser approach that allowed for multiple activities to be treated as a single collective project. ${ }^{44}$ The ability to aggregate payments across projects, as well as over time in single jurisdictions, would make disclosure less granular and thus allow

\footnotetext{
${ }^{41}$ The SEC stated that "[a]lthough the joint resolution vacated the 2016 Rules, the statutory mandate under Section 13(q) of the Exchange Act remains in effect. As a result, the Commission is statutorily obligated to issue a new rule." Disclosure of Payments by Resource Extraction Issuers, 85 Fed. Reg. at 2526.

${ }^{42}$ See Oxfam America and EarthRights International, Comment Letter on Proposed Rule 13q-1, at 30-31 (Mar. 23, 2020), https://www.sec.gov/comments/s7-24-19/s72419-6984657-214635.pdf; Susan RoseAckerman, Comment Letter on Proposed Rule 13q-1 (Mar. 4, 2020), https://www.sec.gov/comments/s724-19/s72419-6911526-211213.pdf; see also 15 U.S.C. § 78m(q)(2)(A) (2018).

${ }^{43}$ See Elise J. Bean, Comment Letter on Proposed Rule 13q-1, at 8-9 (Apr. 29, 2020), https://www.sec.gov/comments/s7-24-19/s72419-7135311-216167.pdf; Rose-Ackerman, supra note 42; cf. Daniel Farber et al., Comment Letter on Proposed Rule 13q-1, at 2 (Mar. 16, 2020), https://www.sec.gov/comments/s7-24-19/s72419-6960389-212777.pdf.

${ }_{4}^{4}$ See Joseph Kraus, The ONE Campaign, Comment Letter on Proposed Rule 13q-1, at 2 (Mar. 25, 2020), https://www.sec.gov/comments/s7-24-19/s72419-6996927-214761.pdf; Oxfam America, supra note 42, at 30-41; Kathleen Brophy, Publish What You Pay, Comment Letter on Proposed Rule 13q-1, at 36-40 (Mar. 16, 2020), https://www.sec.gov/comments/s7-24-19/s72419-6961610-212816.pdf.
} 
energy companies greater ability to hide bribes and other improper payments to foreign officials - in direct contradiction to the purpose of section 1504 of the Dodd-Frank Act.

In seeking to comply with one statute - the CRA - the SEC proposed a new rule that may have diverged too drastically from its prior rule and, in doing so, failed to conform to the text and purpose of another statute - the Dodd-Frank Act. Instead of solving the CRA conundrum, what the SEC proposed would have crashed directly into it.

\section{Solving the CRA Conundrum}

Agencies need a solution to the CRA conundrum. How can they keep from adopting a rule that is "substantially the same" as a disapproved rule when a substantive statute has clearly mandated that agencies adopt rules along the lines of those that Congress has subsequently disapproved? To solve the CRA conundrum, agencies need to have a clearer understanding of how much modification the CRA compels them to make if they seek to reinstate one of their rules that has been disapproved. The answer, as will become evident, lies in how the words "substantially the same" should be understood. These words, like many words in statutes that

must be interpreted, cannot be assessed in the abstract. They need to be understood in the context of an administrative agency that is carrying out responsibilities authorized, and sometimes dictated, by other statutes. The key to resolving the CRA conundrum lies in situating the assessment of what is "substantially the same" by looking at the facets of the rule over which the agency had discretion. In this Part, I will show that the test under the CRA is whether the discretionary facets between two rules are substantially similar. 
If one were to approach the CRA's "substantially the same" provision just in the abstract, the challenge for an agency would be similar to those that arise whenever statutes contain highly ambiguous language. The word "substantially," after all, evinces no bright line.

Consider an agency that issues a hypothetical rule that consists of, say, 100 words. If that rule were disapproved under the CRA and the agency subsequently issued a new rule that contained the same 100 words in identical order, the new rule would not only be substantially the same - it would be exactly the same. But what if the new rule eliminated one word? It would still seem rather obviously to be "substantially the same" as the original 100 -word rule that had been disapproved. Yet exactly how many words would need to be eliminated, added, or changed before the new rule would no longer be "substantially the same" as the rule that had been disapproved? Would ten words need to be changed? 20? 60? 70?

Other questions could be asked about a hypothetical 100-word rule. Suppose an agency changed all 100 words but the new rule retained the same meaning — that is, it still obligated the same individuals or entities to undertake or avoid the same actions. Would this new rule no longer be "substantially the same" as the old one simply because the words were different but the meaning was the same? Or what if the new rule imposed different obligations on different individuals or entities but still was expected to achieve the same overall benefits to society and impose the same overall costs?

The text of the CRA does not provide answers to these questions. More importantly, when it comes to the CRA conundrum, the text does not offer any answer either to what an agency should do in the face of a competing command from another, substantive statute that requires it to adopt a rule along the lines of one that Congress has disapproved. The risk that 
agencies will face such competing commands is great in the modern era where so much law is grounded in statutes and executed via the adoption of administrative rules - many of which agencies are compelled by substantive statutes to adopt. The Dodd-Frank Act, for example, contains explicit provisions requiring agencies, including the SEC, to adopt nearly 250 specific rules. $^{45}$

In these circumstances, when an agency is obligated to create a particular rule by another statute and yet Congress disapproves such a rule under the CRA, the CRA conundrum calls out for resolution. ${ }^{46}$ That resolution is actually facilitated by the very imprecision of the CRA's use of the word "substantially." That ambiguity is a feature, not a bug, for it implies that the CRA is not intended to impose a rigid restriction on an agency.

Congress was clear that a CRA disapproval resolution does not alleviate an agency's obligation to comply with another legal requirement that an agency adopt a rule similar to the

\footnotetext{
${ }^{45}$ DAVIS POLK, SUMMARY OF THE DODD-FRANK WALl STREET REFORM AND CONSUMER PROTECTION ACT, ENACTED INTO LAW ON JULY 21, 2010, at i (July 21, 2010), https://www.davispolk.com/files/files/Publication/7084f9fe-6580-413b-b870b7c025ed2ecf/Presentation/PublicationAttachment/1d4495c7-0be0-4e9a-ba77f786fb90464a/070910_Financial_Reform_Summary.pdf ("By our count, the Act requires 243 rulemakings ....").

${ }^{46}$ An agency might, of course, permissibly modify an earlier construction of ambiguous aspects of the substantive statute. A new agency interpretation of any such ambiguous provisions in the substantive statute might well prove reasonable and entitled to deference, even when its earlier interpretation was also reasonable and entitled to deference. Chevron U.S.A. Inc. v. Nat. Res. Def. Council, Inc., 467 U.S. 837, 863 (1984) (“An initial agency interpretation is not instantly carved in stone.”). By revising its interpretation of such ambiguous provisions, the agency may be able to make its post-disapproval rule substantially different than its pre-disapproval rule. This would be another way of giving effect to both statutes, but this possibility amounts to a retreat from the assumption underlying the analysis in this article: namely, that the CRA and the substantive statute are in tension. To the extent that the substantive statute can be reinterpreted to eliminate that tension and to allow the agency room to make what would colloquially be deemed a substantially different rule, then there really would be no CRA conundrum presented.
} 
one disapproved. ${ }^{47}$ The text of the CRA expressly contemplates that other statutes impose rulemaking requirements on agencies, and it makes clear that a resolution of disapproval does not repeal those requirements. It does so in Section 803 , which provides a "special rule" on statutory deadlines, expressly extending by one year after a disapproval resolution's enactment any substantive statute's deadline for promulgating a rule. ${ }^{48}$ Section 803 would not have been needed if Congress had intended a resolution of disapproval to be construed as a repeal of a substantive statute's requirement to promulgate a rule.

Furthermore, it is a longstanding, firmly entrenched principle of statutory interpretation that repeals of statutes should be stated expressly. As early as 1814, the Supreme Court has made it clear that repeals by implication are disfavored. ${ }^{49}$ Yet a CRA resolution of disapproval must comport exactly with sparse language provided for such resolutions in the CRA statute itselfnone of which even remotely expresses any affirmative intent to repeal provisions of another statute. ${ }^{50}$ The operative language in a CRA resolution of disapproval just states that Congress "disapproves the rule ... and such rule shall have no force or effect." 51

The Supreme Court has described the general presumption against implied repeals as a "cardinal rule," stating that "[w]here there are two acts upon the same subject, effect should be

\footnotetext{
${ }^{47}$ On obligation alleviation, see Cary Coglianese, Obligation Alleviation During the COVID-19 Crisis, REG. REV. (Apr. 20, 2020), https://www.theregreview.org/2020/04/20/coglianese-obligation-alleviationduring-covid-19-crisis/; Cary Coglianese, Gabriel Scheffler, \& Daniel E. Walters, Unrules, 73 STAN. L. REV. (forthcoming June 2021).

485 U.S.C. $\$ 803$ (2018).

${ }^{49}$ Hartford v. United States, 12 U.S. (8 Cranch) 109, 109 (1814) ("[A] repeal by implication ought not to be presumed unless from the repugnance of the provisions the inference be necessary and unavoidable.").

${ }^{50}$ The CRA specifies the precise terms that are to appear in a joint resolution of disapproval that is eligible for the CRA's special legislative procedures and triggers other facets of the CRA. 5 U.S.C. $\S$ 802(a). For the actual text of the joint resolution disapproving the SEC's 2016 rule, see supra note 36. That joint resolution comports with $\S 802(a)$.

${ }^{51} 5$ U.S.C. $\S 802(a)$.
} 
given to both if possible." 52 It has explained that, "[i]n the absence of some affirmative showing of an intention to repeal, the only permissible justification for a repeal by implication is when the earlier and later statutes are irreconcilable." 53

But even if the CRA were to be viewed as in hopelessly irreconcilable conflict with another statute, this does not mean that others statute's provisions must give way. Returning to the Dodd-Frank Act by way of illustration, even if there existed an irreconcilable difference between that Act and the CRA, it would be the Dodd-Frank Act that would impliedly repeal any application of section 801(b)(2) of the CRA. This conclusion follows directly from two other longstanding, well-accepted principles of statutory construction. First, specific statutes (such as the Dodd-Frank Act) take priority over general statutes (such as the CRA). ${ }^{54}$ Second, later statutes prevail over earlier ones. ${ }^{55}$ The Dodd-Frank Act was enacted in 2010, while the CRA was adopted in 1996 - meaning that, if the provisions are assumed irreconcilable, then the Dodd-Frank Act's provisions prevail.

\footnotetext{
52 Posadas v. Nat'l City Bank, 296 U.S. 497, 503 (1936).

${ }^{53}$ Morton v. Mancari, 417 U.S. 535, 550 (1974) ("In the absence of some affirmative showing of an intention to repeal, the only permissible justification for a repeal by implication is when the earlier and later statutes are irreconcilable.”); see also, e.g., Branch v. Smith, 538 U.S. 254, 273 (2003) (plurality opinion) ("We have repeatedly stated . . . that absent a clearly expressed congressional intention, repeals by implication are not favored." (citations and internal quotation marks omitted)).

${ }^{54}$ Morton v. Mancari, 417 U.S. 535, 550-51 (1974) ("Where there is no clear intention otherwise, a specific statute will not be controlled or nullified by a general one, regardless of the priority of enactment."); United States v. Estate of Romani, 523 U.S. 517, 532 (1998) (noting that "it would be anomalous to conclude that Congress intended the priority statute to impose greater burdens on the citizen than those specifically crafted").

${ }^{55}$ Food and Drug Admin. v. Brown \& Williamson Tobacco Corp., 529 U.S. 120, 144 (2000) (explaining that "a specific policy embodied in a later federal statute should control our construction of the [earlier] statute, even though it ha[s] not been expressly amended.") (citing United States v. Estate of Romani, 523 U.S. at 530-531); see also Posadas v. National City Bank of New York, 296 U.S. 497, 503 (1936) explicating the "well-settled" principles that "[w]here provisions in ... two acts are in irreconcilable conflict, the later act to the extent of the conflict constitutes an implied repeal of the earlier one" and that "if the later act covers the whole subject of the earlier one and is clearly intended as a substitute, it will operate similarly as a repeal of the earlier act").
} 
Admittedly, the resolution of disapproval comes last of all, after the enactment of the Dodd-Frank Act. But disapproval resolutions themselves do not contain any prohibition on the adoption of a substantially similar rule; only the 1996 CRA does. ${ }^{56}$ If any irreconcilable conflict were to arise between the CRA and a statute mandating the adoption of a rule, it would only be because of section 801(b)(2) of the CRA — the more general statute and, presumably in almost all cases, the later one too ${ }^{57}$-not because of any provision in the disapproval resolution.

All this said, there exists no reason to assume an irreconcilable conflict between any substantive statute and the CRA. This is because the phrase "substantially the same" is flexible and can and should be construed in a way that gives effect to both the CRA and the substantive statute underlying a disapproved rule. The way to reconcile the two statutes is to recognize that what constitutes substantial similarity under the CRA depends on the degree of discretion afforded to the agency under the substantive statute.

To see how this is so, let us return to the hypothetical example of a 100-word rule that has been disapproved by Congress under the CRA. Let us further assume for the sake of analysis that 70 of those words - the precise words themselves—-had been expressly dictated by a substantive statute obligating an agency to issue the rule. How should a new rule that follows a disapproved one be judged if it contains those same 70 words but makes considerable changes to the 30 words that were not required by the substantive statute? Taking the overall 100 words into

\footnotetext{
${ }^{56}$ See supra note 36 . Again, the language in a disapproval resolution must accord with the exact language the CRA expressly specifies for such a resolution - none of which states or even implies anything about the "substantially the same" limitation.

${ }^{57}$ Most statutes mandating the adoption of specific rules call for these rules to be adopted within a limited timeframe of generally less than a few years after the passage of the statute. At this point in time, given that the CRA was adopted nearly thirty years ago, any agency rules being adopted now in response to a statutory mandate will almost certainly be at the behest of statutes adopted after the CRA.
} 
account, perhaps it might seem as if the new rule is still substantially similar to the old, disapproved rule, as 70 percent of the words are identical to the old rule. But that cannot be the correct conclusion, as it would imply that the CRA has repealed the substantive statute that required those 70 words - a result which, as already noted, also cannot be the correct conclusion under well-accepted statutory interpretation principles.

The better conclusion is that the agency, having genuinely changed its approach in the portion of the rule over which it had discretion (that is, the 30 remaining words), acted in a manner faithful both to section 801(b)(2) of the CRA and to the commands within its underlying substantive statute. In fact, this is not only the better conclusion about how to construe the words "substantially the same" in the CRA; it is the only possible way to understand these words in the context of other constraining substantive commands on an agency imposed by other statutes.

To return to the SEC's resource extraction disclosure rule, it is now possible to see how this helps resolve the CRA conundrum in a real-world setting. Given the specificity and detail in section 1504 of the Dodd-Frank Act — such as its requirement that an SEC rule mandate disclosure of "any payment" 58 — the SEC found itself in a position not at all unlike the hypothetical statute that compels the use of 70 percent of the words in a rulemaking. It could not alter its rule to require disclosure of only some payments, nor merely to mandate disclosure of an overall payment amount. It had to require disclosure still of "any payment," as that statutory term constrained the SEC's discretion.

I do not claim, of course, that it is possible to quantify the level of discretion left to the SEC in developing its Rule 13q-1 in numerical form. Nevertheless, it is clear that the SEC has

\footnotetext{
${ }^{58}$ See supra notes 6 and 42 and accompanying text.
} 
much less discretion over the contents of its resource extraction payments rule than it would have under, say, a rule adopted under a more general authorization to create rules as "may be necessary or appropriate," ${ }^{59}$ sweeping language of a kind not infrequently found in statutory authorizations of rulemakings. ${ }^{60}$

Every agency-promulgated rule will have multiple issues that need to be addressed or different dimensions to be covered - the who, what, when, and how of rulemaking. ${ }^{61}$ In some cases, as with section 1504 of the Dodd-Frank Act, the substantive statute will dictate how some of these issues or dimensions are to be addressed. In the case of the SEC's Rule 13q-1, for example, some of these issues or dimensions had also been effectively dictated by prior judicial rulings, such as the district court's decision on the earliest version of the SEC's rule. ${ }^{62}$

When it comes to compliance with the CRA's "substantially the same" limitation, the interpretation that reconciles that limitation with the requirement of a substantive statute must consider as unchangeable those parts of the rule that Congress has effectively written for the agency by requiring that the agency include in its rule certain features, definitions, or provisions. The task in determining whether a subsequent rule is "substantially the same" as a disapproved

\footnotetext{
${ }^{59}$ See, e.g., 15 U.S.C. $§ 78 \mathrm{u}-6(\mathrm{j})$ (2018) ("The Commission shall have the authority to issue such rules and regulations as may be necessary or appropriate to implement the provisions of this section consistent with the purposes of this section.").

${ }^{60}$ For additional examples, see Cary Coglianese, Chevron's Interstitial Steps, 85 GEO. WASH. L. REV. 1339, 1350-1351 (2017).

${ }^{61}$ The SEC's preamble to its proposed rule seems to recognize as much when it refers to "the amount, granularity, timing, scope of, and liability for, the required disclosures." Disclosure of Payments by Resource Extraction Issuers, 85 Fed. Reg. 2522, 2527 (proposed Jan. 15, 2020) (to be codified at 17 C.F.R. pts. 240, 249b). For related but general discussions, see Cary Coglianese, Dimensions of Delegation, 167 U. PA. L. REV. 1849, 1863-1870 (2019); Cary Coglianese, Regulation's Four Components, REG. REV. (Sept. 17, 2012), https://www.theregreview.org/2012/09/17/regulations-fourcore-components/.

${ }^{62}$ See Am. Petroleum Inst. v. SEC, 953 F. Supp. 2d 5, 11 (D.D.C. 2013).
} 
rule simply becomes one of assessing how similar the former rule is to the latter in those aspects over which the agency has discretion.

The basic idea, in other words, is to think spatially about agency discretion. To make a determination of whether two rules are "substantially the same" for CRA purposes, an agency should first consider how much of the regulatory "space" the substantive statute has allowed the agency to fill. The agency's obligation under the CRA is then to make sure that any new rule that follows a disapproved one is not substantially the same within the remaining space that the substantive statute has left for the agency to fill.

If a statute gives an agency virtually unbounded space within which to design a rulesay, by merely authorizing the agency to adopt a rule that is "appropriate and necessary" or that simply advances the "public interest"- then it will be appropriate to compare a new rule with a disapproved rule one on virtually every dimension. In such a situation, determining whether two rules are substantially can be conceived as basically calling for the use of the "compare documents" function on Microsoft Word to see how many words are different between the two rules. But if a statute gives much less direction to an agency, and actually spells out features and provisions that a rule must contain, then the appropriate test of similarity demands first putting to the side those facets of the relevant agency rules that are mandatory and then comparing what is left. One might even say that, if a statute already fills up half of the proverbial décor in a regulatory "room," the test under the CRA is to compare what the agency has done in terms of decorating the room's other half.

For an agency such as the SEC, then, this spatial understanding of regulation means that it should not, cannot, and, more notably, need not violate the Dodd-Frank Act in an effort to 
make a subsequent rule sufficiently different from a disapproved one to comport with the CRA. The SEC simply needed to ensure that its new resource extraction disclosure rule was substantially different with respect to those facets of the rule over which the agency had discretion.

\section{On the Applicability of Chevron and Legislative History}

What remains to be considered are two additional arguments for reconciling the demands of a substantive statute such as the Dodd-Frank Act with the constraints of the CRA: Chevron deference, and a reliance on legislative history. Perhaps what counts as "substantially the same" should be analyzed using the Chevron framework - which would suggest that the very ambiguity of "substantially" should lead courts to allow agencies to resolve these matters on their own. Or perhaps the answers for how agencies should respond in the face of a CRA disapproval resolution depends on mining the legislative history underneath that very resolution.

Although both of these alternative perspectives have emerged to varying degrees as contenders in the quest for resolution of the CRA conundrum, neither are persuasive nor even helpful in solving this puzzle of competing statutory dictates. The failings of these alternative perspectives only reinforces that the conundrum's resolution depends on the spatial understanding of regulatory discretion articulated in Part II and on an assessment of similarity within the context of how an agency has designed a new rule within its discretionary space.

\section{A. Chevron Deference}

As explained in Part II of this article, a spatial understanding of regulatory discretion reasonably accommodates both the CRA and the Dodd-Frank Act. The very reasonableness of 
this understanding might lead some observers to want to invoke the framework articulated in Chevron, U.S.A., Inc. v. Natural Resources Defense Council, Inc. ${ }^{63}$ After all, Chevron-which remains good law, even if the Supreme Court seems to ignore it ${ }^{64}$ — calls upon courts to defer to agencies' reasonable understanding of ambiguous statutory provisions. It might seem that few statutory provisions could be more ambiguous than the CRA's "substantially the same" provision. ${ }^{65}$

The Chevron approach to resolving the CRA conundrum might actually take two subtly distinct forms. The first form would simply use Chevron to bolster the spatial account developed in Part II. In other words, applying this first form of the Chevron argument might merely imply that an agency such as the SEC should receive deference if it were to adopt a spatial approach to interpreting the CRA, given that the CRA's "substantially the same" terms are ambiguous and that the spatial understanding is reasonable.

A second, and more expansive, form of the Chevron argument would be to use it to make the CRA conundrum disappear altogether. The conundrum comes about, this form of the argument would go, only because of an ambiguity created by two statutes' provisions being seemingly at odds with each other. In the face of this ambiguity over the conflict between the

${ }^{63}$ Chevron, U.S.A., Inc. v. Natural Resources Defense Council, Inc., 467 U.S. 837-866 (1984).

${ }^{64}$ Richard J. Pierce, Jr., Is Chevron Deference Still Alive?, REG. REV. (July 14, 2022), https://www.theregreview.org/2022/07/14/pierce-chevron-deference/.

${ }^{65}$ Although still a standing precedent, Chevron's future status remains an open question, as some Supreme Court justices question the doctrine's constitutionality and others have criticized or ignored it for other reasons. If the Court should repudiate or abandon Chevron, that will obviously mean it cannot be used to solve the CRA conundrum. But if Chevron deference does manage to survive, even if in limited circumstances such as when relevant statutory provisions contain "broad and open-ended terms like 'reasonable,' 'appropriate,' 'feasible,' or 'practicable"' (as Justice Brett Kavanaugh once urged), then the Chevron arguments considered in the text of this article will remain plausible to consider. $C f$. Brett M. Kavanaugh, Fixing Statutory Interpretation, 129 HARV. L. REV. 2118, 2153 (2016). They will just not be persuasive arguments for the reasons provided in the text. 
two statutes, Chevron's Step One would be satisfied. The argument would then be that the courts should defer to the agency's new rule as long as it is reasonable, as the new rule by definition would reflect the agency's resolution of the ambiguity created by the conflicting statutes. Effectively, this is just a way of the courts saying, essentially, "don't worry, be happy." ${ }^{66}$ As long as what the agency proposes to do in response to a disapproval resolution seems reasonable, then any statutory ambiguity created by an apparent conflict with the CRA 's "substantially the same" should be enough to make the agency's rule eligible for deference and for the courts to allow it to proceed.

But under either form of the Chevron argument, a court would not be justified in giving an agency deference in the face of ambiguity created by the CRA's terminology. Chevron deference is grounded on an implied delegation to an agency, ${ }^{67}$ and a general procedural statute such as the CRA, which applies to agencies across the entire federal government, contains no implied delegation to any individual agency. ${ }^{68}$ In the SEC example, even though Congress has authorized the SEC to implement aspects of the Dodd-Frank Act, it has not delegated to the SEC (nor to any other agency) the authority to construe ambiguous terms in the CRA nor to resolve ambiguities created by the CRA's terms. Chevron deference is simply not available to agencies for their interpretations of procedural statutes generally applicable across the federal government, no matter how reasonable those interpretations may be. ${ }^{69}$

\footnotetext{
${ }^{66}$ BOBBY MCFERRIN, DON'T WORRY BE HAPPY (EMI-Manhattan Records 1988).

${ }^{67}$ See Cary Coglianese, Chevron's Interstitial Steps, 85 GEO. WASH. L. REV. 1339-1391 (2017).

${ }^{68}$ See Metro. Stevedore Co. v. Rambo, 521 U.S. 121, 137 n.9 (1997) (denying Chevron deference to an agency's interpretation of the Administrative Procedure Act because it "is not a statute that the [agency] is charged with administering").

${ }^{69}$ See Michael J. Cole, Interpreting the Congressional Review Act: Why the Courts Should Assert Judicial Review, Narrowly Construe "Substantially The Same," and Decline to Defer to Agencies Under Chevron, 70 ADMIN. L. REV. 53, 94-101 (2018) (arguing that the SEC cannot win Chevron deference for an
} 
The issue of Chevron deference is thus largely a distraction. The spatial understanding of "substantially the same" presented in Part II is not merely a reasonable interpretation of the CRA in a setting where a statute has compelled an agency to adopt a specific rule. It is also the only plausible interpretation that reconciles both the CRA and the substantive statute. A court would need to adopt this view of the CRA at Chevron Step One and could not proceed to Step Two, as that would imply that there exist alternative reasonable ways to resolve the CRA conundrum. ${ }^{70}$ The reality is that the spatial understanding in Part II is the only way to respond and fulfill the long-held principle of statutory construction that when two statutes appear to clash, "effect should be given to both [statutes] if possible."ㄱ1

Even if arguments urging Chevron deference were more convincing, such deference could never sustain an agency position that construes the CRA's "substantially the same" provision in a manner that allows the agency to ignore mandatory terms of a substantive statute. Such a direct conflict with a substantive statute could never be a reasonable one.

Furthermore, no court could give proper deference to an interpretation that a CRA disapproval resolution had amended a substantive statute and released the agency from its responsibility to comply with the latter statute's requirements. Such a claim that a CRA disapproval resolution amends or repeals a substantive statute would also never be reasonable. The text of such a resolution of disapproval is stipulated by the CRA itself to read quite sparsely:

interpretation of a general statute such as the CRA); Arianna Skibell \& Geof Koss, SEC Rule Repeal Sets Stage for Unprecedented Legal Fight, E\&E DAILY (Feb. 10, 2017), https://www.eenews.net/eedaily/2017/02/10/stories/1060049856 (attributing a similar conclusion to the author of this article).

${ }^{70}$ Cf. Nat'l Cable \& Telecomms. Ass'n v. Brand X Internet Servs., 545 U.S. 967 (2005); see generally Coglianese, supra note 60, at 1378-1383 (explaining the meaning of Step Two and how a court that reaches it must have concluded that there exist more than one possible meaning of a statute).

${ }^{71}$ Posadas v. Nat'l City Bank, 296 U.S. 497, 503 (1936). 
"That Congress disapproves the rule submitted by the [agency] relating to [the rule being disapproved], and such rule shall have no force or effect." 72 Nothing in a resolution worded this way — as disapproval resolutions must expressly be worded under the CRA — appears in any relevant way to be ambiguous. Nor is it possible to see how any interpretation of this text could ever sustain a reasonable interpretation that another statute has been effectively amended or repealed by such a resolution.

\section{B. Legislative History}

In the preamble to the SEC's proposed rule in the resource extraction disclosure rule, the agency looked to the legislative history of the joint resolution of disapproval for guidance as to what its options may be for a subsequent rulemaking. ${ }^{73}$ Some of the SEC's invocation of legislative history was innocuous. For example, the SEC quite appropriately acknowledged that even some members of Congress who voted for the disapproval resolution did so while recognizing that the agency still needed to go back and follow the dictated elements of the Dodd-Frank Act in issuing a new rule. ${ }^{74}$ More concerningly, though, the SEC elsewhere in its preamble cited a problematic passage in the legislative history of the CRA itself, quoting part of

\footnotetext{
725 U.S.C. $\S 802$ (a) (2018).

${ }^{73}$ For example, in its proposed rule, the SEC stated:

Given this legislative history, and the absence of further general guidance from the CRA or specific legislative guidance from Congress addressing the form of a new rulemaking, we looked to the concerns raised by members of Congress during the floor debates on the joint resolution to assist us in developing a rule.
}

Disclosure of Payments by Resource Extraction Issuers, 85 Fed. Reg. 2522, 2526 (Jan. 15, 2020); see also $i d$. at 2528 ("In proposing these provisions and other aspects of this rulemaking, we have striven to achieve an appropriate balance between implementing the statute as required by Congress and addressing the concerns expressed by commenters and members of Congress.); id. at $2528 \mathrm{n}$. 78 (emphasizing that "the estimated cost of compliance of the 2016 Rules and the potential for competitive harm were specifically noted by the members of Congress who voted to disapprove the rules") (citing member statements in the Congressional Record).

${ }^{74}$ Id. at 2526 n.60 (Jan. 15, 2020) ("A number of members who supported the joint resolution noted that the Commission would be obligated to issue a new rule fulfilling the statutory mandate."). 
a flawed claim made by Senate sponsors of the bill that became the CRA. ${ }^{75}$ The flawed claim suggested that the legislative history of a resolution of disapproval could be used to support an agency taking a position on a new rule that would effectively modify or even repeal the relevant substantive statute:

If an agency is mandated to promulgate a particular rule and its discretion in issuing the rule is narrowly circumscribed, the enactment of a resolution of disapproval for that rule may work to prohibit the reissuance of any rule. The authors intend the debate on any resolution of disapproval to focus on the law that authorized the rule and make the congressional intent clear regarding the agency's options or lack thereof after enactment of a joint resolution of disapproval. It will be the agency's responsibility in the first instance when promulgating the rule to determine the range of discretion afforded under the original law and whether the law authorizes the agency to issue a substantially different rule. Then, the agency must give effect to the resolution of disapproval. ${ }^{76}$

But clearly a resolution of disapproval in no way can work to "prohibit the reissuance" of a rule that is mandated by another duly enacted statute. As already noted, disapproval resolutions must follow a specific — and sparse — form specified in the CRA. ${ }^{77}$ Nothing in this sparse language

\footnotetext{
${ }^{75}$ The legislative history of the CRA consists mainly of a joint statement of Senate sponsors introduced in the Senate only after the House had already passed the bill and only "immediately" before passage in the Senate under a motion for unanimous consent. See 142 CONG. REC. S3683 (daily ed. April 18, 1996) (statement of Sens. Nickles, Reid \& Stevens). Only later, after the President signed the CRA, did relevant committee chairs in the House submit into the record the statement of the Senate sponsors. Id.

${ }^{76} 142$ CONG. REC. S3686 (daily ed. April 18, 1996) (statement of Sens. Nickles, Reid \& Stevens). In its proposed rule, the SEC quoted all but the first sentence of this passage. Disclosure of Payments by Resource Extraction Issuers, 85 Fed. Reg. at 2526 n.63.

${ }^{77}$ See supra notes 36 and 50 and accompanying text.
} 
even remotely speaks to another statute at all, let alone could constitute a legislative repeal of another statute's requirement that an agency issue a regulation. Moreover, as noted earlier, Section 803 of the CRA expressly contemplated that an agency which had faced a deadline to issue a disapproved rule would still need to re-issue the rule. ${ }^{78}$

Just as the legislative history of the CRA provides no basis for concluding that a disapproval resolution repeals or amends another statute, it would be problematic for an agency to rely on any legislative history leading up to a disapproval resolution as a basis for implying an amendment or repeal of another statute. Legislative history can be an aid in understanding a statute and giving it meaning, but it is not the law adopted by Congress. ${ }^{79}$ Moreover, legislative history needs to be at least connected to statutory law and used in service of giving meaning to it. Because none of the words contained in a CRA disapproval resolution speak in any way to amending or repealing another statute, any legislative history that may pertain to how an entirely separate statute ought to be construed would be devoid of any connection to the disapproval resolution. All the resolution does is remove the force and effect of a specific agency rule; it does not speak at all to the statute underlying the disapproved rule. ${ }^{80}$

In the end, regardless of what might transpire in legislative deliberations leading up to a resolution of disapproval, nothing in such a resolution could ever make legislators' views about a prior enacted law germane to an understanding of the actual resolution adopted. Contrary to what the Senate sponsors of the CRA claimed in their joint statement, Congress simply cannot act through a CRA disapproval resolution, or through statements in the legislative history leading up

\footnotetext{
${ }^{78}$ See supra note 48 and accompanying text.

${ }^{79}$ See, e.g., Epic Systems Corp. v. Lewis 138 S. Ct. 1612, 1631 (2018) (“[L]egislative history is not the law.").

${ }^{80}$ See supra notes 36 and 50 and accompanying text.
} 
to such a resolution, to bypass the normal bicameral and presentment requirements to amend a statute that requires an agency to promulgate a specific rule. ${ }^{81}$ If Congress wants to repeal or change the parameters of a substantive statute's obligation on an agency, it cannot do so via the CRA process which is directed at administrative rules. It needs to adopt separate legislation repealing or changing the substantive statute.

\section{Conclusion}

Until Congress repeals or amends a substantive statute that requires the promulgation of a specific rule, an agency is bound to respect the statute's requirements. And a court can be expected to hold the agency to those obligations.

In the case of an agency such as the SEC, which faced both a substantive statute's obligations under the Dodd-Frank Act and a resolution of disapproval under the CRA of an earlier version of a rule established to fulfill the agency's obligations under the Dodd-Frank Act, the disapproval resolution does not, as the SEC recognized, alleviate the agency's underlying substantive statutory obligations. That means that if the SEC is required under the Dodd-Frank Act to adopt a rule compelling energy extraction companies to disclose publicly "any payment" they make to governments, then it cannot propose an altogether different kind of disclosure requirement merely to make its rule different from an earlier one that Congress disapproved.

An agency need not, and must not, violate its obligations under substantive statutes mandating specific rules to comport with the CRA because, even when a rule is disapproved

\footnotetext{
${ }^{81}$ Cf. INS v. Chadha, 462 U.S. 919, 954-55 (1983) (holding that modification of a statute delegating authority to an agency requires "bicameral passage [in Congress] followed by presentment to the President").
} 
under the CRA, there is a readily available and eminently sensible way of overcoming the CRA conundrum. When a statute mandates that an agency adopt a rule, such Dodd-Frank did with respect to Rule 13q-1, the question is not whether to assess "substantially the same" in the abstract. Rather, those terms in the CRA must be understood by reference to the degree of agency discretion that is afforded in the original, substantive statute. It is telling that, in the end, when finalizing its proposed rule, the SEC articulated an understanding of "substantially the same" that follows the analysis presented in this article. The SEC explicitly recognized the principle that it cannot weaken a disclosure regime in contravention of requirements in the Dodd-Frank Act, even if in the name of satisfying the CRA. ${ }^{82}$ Instead, the SEC stated that the test for compliance with the CRA should be based only on the "central discretionary determinations" the agency had made in its disapproved rule. ${ }^{83}$

In an era of increasing dependence on statutory law and administrative rulemaking, it is important to make clear that agencies cannot use the CRA to expand their discretion by revising aspects of a previous rule that they were required to fulfill the agency's obligations under a substantive statute. In circumstances where a substantive statute spells out in detail what a rule must entail, an agency may still have some degree of discretion, if only to offer the possibility of granting limited waivers or perhaps phasing in or otherwise delaying the date for compliance

\footnotetext{
${ }^{82}$ The analysis presented in this article had been presented to the Commission in a comment submitted by the author to the agency in response to its proposed rule.

${ }^{83}$ Securities and Exchange Commission, Disclosure of Payments by Resource Extraction Issuers, 86 Fed. Reg. 4,662, 4,665 (Jan. 15, 2021). That said, members of the Commission disagreed over what was actually discretionary under the Dodd-Frank Act. By a 3-2 vote along party lines, the Commission approved the proposed rule's loosening of the definition of energy projects and its allowance for the aggregation of payment information, claiming these changes did not conflict with the Dodd-Frank Act's requirement of reporting of "any" payment. Notably, the two dissenting Commissioners argued that these changes did not comply with the Dodd-Frank Act. Crenshaw, supra note 5; Allison Herren Lee, Statement on Rules Governing the Disclosure of Payments by Resource Extraction Issuers (Dec. 16, 2020), https://www.sec.gov/news/public-statement/lee-resource-extraction-2020-12-16.
} 
with a new rule. In such situations where agencies have been given virtually no other discretion under a substantive statute as to the form and content of a rule, the inclusion of such a limited exemption option or a delayed compliance date would suffice to satisfy the CRA by making the subsequent rule substantially different in the relevant space of available agency discretion. ${ }^{85}$

A spatial understanding of what it means to be "substantially the same" holds the key to reconciling the apparent conundrum created when a general procedural statute, such as the CRA, comes into tension with the requirements of a more specific substantive statute, such as the Dodd-Frank Act. Only under such a spatial approach, focused on an agency's available discretion, can the agency give due effect to its obligations under both the CRA and the substantive statute.

${ }^{85}$ Skibell \& Koss, supra note 67 (noting my observation that "delaying the compliance period or providing more opportunities for waivers" could suffice to make a new rule substantially different from an old one). 